The Holy Portolano

Le Portulan sacré 


\section{Scrinium Friburgense}

Veröffentlichungen des Mediävistischen Instituts

der Universität Freiburg Schweiz

Herausgegeben von

Michele Bacci · Hugo Oscar Bizzarri · Elisabeth Dutton

Christoph Flüeler · Eckart Conrad Lutz · Hans-Joachim Schmidt

Jean-Michel Spieser · Tiziana Suarez-Nani

Band 36

De Gruyter 


\section{The Holy Portolano}

The Sacred Geography of Navigation in the Middle Ages

\section{Le Portulan sacré}

La géographie religieuse de la navigation au Moyen Âge

\section{Fribourg Colloquium 2013 \\ Colloque Fribourgeois 2013}

Edited by / Edité par

Michele Bacci · Martin Rohde 
Veröffentlicht mit Unterstützung des Hochschulrates der Universität Freiburg Schweiz

$$
\begin{gathered}
\text { ISBN 978-3-II-0364I 8-7 } \\
\text { e-ISBN (PDF) 978-3-II-036425-5 } \\
\text { e-ISBN (EPUB) 978-3-II-038576-2 } \\
\text { ISSN I } 422-4445
\end{gathered}
$$

Library of Congress Cataloging-in-Publication Data

A CIP catalog record for this book has been applied for at the Library of Congress.

\section{Bibliographic information published by the Deutsche Nationalbibliothek.}

The Deutsche Nationalbibliothek lists this publication in the Deutsche Nationalbibliografie; detailed bibliographic data are available on the Internet at http://dnb.dnb.de.

(C) 2014 Walter de Gruyter GmbH, Berlin/Munich/Boston

Typesetting: Mediävistisches Institut der Universität Freiburg Schweiz Printing and binding: Hubert \& Co. GmbH \& Co. KG, Göttingen @ Printed on acid-free paper

Printed in Germany www.degruyter.com 


\section{Contents / Sommaire}

Michele Bacci (Fribourg) - On the Holy Topography of Sailors:

An Introduction . . . . . . . . . . . . . . . 7

Patrick Gautier Dalché (Paris) - Eléments religieux dans les représentations textuelles et figurées de la Méditerranée .... I I 7

Michel Balard (Paris) - Le peregrinagium maritimum en Méditerranée $\left(\mathrm{XIV}^{\mathrm{e}}-\mathrm{XV}^{\mathrm{e}} \mathrm{s}\right.$. $\ldots \ldots \ldots . \ldots \ldots$

David Jacoby (Jerusalem) - Ports of Pilgrimage to the Holy Land, Eleventh-Fourteenth Century: Jaffa, Acre, Alexandria . . . . . s I

Nada Helou (Beyrouth) - Les lieux sacrés de Beyrouth au Moyen Âge.

Les deux églises de Saint-Georges . . . . . . . . . . . . . . 73

Rafat Quirini-Poptarwski (Kraków) - Seaside Shrines in the Late Mediaeval Black Sea Basin. Topography and Selected Historical and Art Historical Questions . . . . . . . . . . . 95

Chryssa Maltezou (Atene) - I monaci dell'isola dell'Apocalisse tra preghiera, spionaggio e navigazione (XV-XVIII sec.) . . . . . I2I

Maria Georgopoulou (Athens) - The Holy Sites of Candia . . . . I I33

Joško Belamarić (Split) - The Holy Portolano. The Sacred Geography of Navigation along the Dalmatian coast in the Middle Ages . . . . . . . . . . . . . . . . . I59

Mario Bubagiar (Malta) - The Pauline Sacred Geography of the Maltese Islands and their Maritime Shrines . . . . . . . . . I85 
Vinni Lucherini (Napoli) - Strategie di visibilità dell'architettura sacra nella Napoli angioina: la percezione da mare e la testimonianza di Petrarca . . . . . . . . . . . . . . . . . I97

Valentina Ruzzin (Genova) - Alcune osservazioni in merito al ritrovamento della $<$ Bonna Parolla $>$ genovese . . . . . . . . 22 I

Valeria Polonio (Genova) - La Liguria e la sua originalità: una variante del < Portolano sacro >

Francesca Español (Barcelona) - Le voyage d'outremer et sa dimension spirituelle. Les sanctuaires maritimes de la côte catalane . . . . . . . . . . . . . . . 257

Amadeo Serra Desfilís (Valencia) - A brave new kingdom: images from the sea and in the coastal sanctuaries of Valencia (XIII-XV centuries) . . . . . . . . . . . . . 283

Adeline Rucquoi (Paris) - Saint-Jacques de Compostelle sur les rives de la Mer Ténébreuse

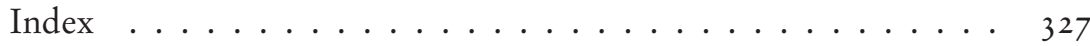

Illustrations . . . . . . . . . . . . . . . . . . . 347 


\title{
A brave new kingdom: images from the sea and in the coastal sanctuaries of Valencia (XIII-XV centuries)
}

\author{
Amadeo Serra Desfilis (Valencia)
}

\section{The birth of a Christian kingdom ${ }^{1}$}

As the Tunisian fleet sailed away from the coast of Valencia, the Muslim population probably felt that their last hope of receiving help had faded in late September I 238. Off the Valencian coast, the Catalan ships of James I could be seen against the horizon. After the conquest, Valencia was a brave new kingdom, inevitably Christian by royal command and by dint of geopolitical circumstance. From this point on, the land of Valencia would be oriented towards Western Christianity and the Mediterranean trade routes. From the beginning, James I had planned to control the newly-conquered lands by founding cities and castles, and by concentrating Christian settlers in coastal areas while most Muslim groups stayed inland or in contested border areas. We shall borrow a description of the new landscape found by the Aragonese king and the settlers who came after him from American historian Robert I. Burns:

Essentially the kingdom of Valencia consisted of a ribbon of fertile coastline, hemmed in along its length by forbidding highlands and mountains. All down this pleasant coast lay a succession of lovely plains -some large and some small- irrigated, prosperous, and strongly defended. Somewhat below the city of Valencia, the shoreline thrust out to form a huge triangle of land. Here the kingdom spread at its widest, and here it erupted into a chaotic tumble of imposing sierras. Beyond this terrible bastion, the former pattern of plain and highland resumed, but now one was entering the region called Murcia.

I This paper has benefitted from the research projects under the titles Memory and Meaning: Use and Perception of the Past (HAR2009-I3209) and Reception, Image and Memory in the Art from the Past (HAR 2013-48794P), both of them financed by the Spanish Ministry of Economy and Innovation at University of Valencia. 
Towns and hamlets covered the Valencian littoral and were scattered into the interior, even in the uninviting mountainous regions. The desolate escarpment at his back directed the Valencian toward the sea, to commerce and to continual contact with other Mediterranean peoples. It was a land of bustling little ports, luxuriant farmlands, well-travelled roads, and proud walled cities like Burriana or Peñíscola in the north, Játiva or Alcira in the south, and Cullera or Murviedro in the centre. As a Christian land, the kingdom of Valencia was to be dominated, in law and in practical life, by the city of Valencia. It is not inappropriate, therefore, to refer to this city as the capital of the kingdom of Valencia. ${ }^{2}$

The spirit of the crusade and the papal bulls accompanied James I and his knights and the conquest advanced with the impulse of a religious exaltation. Sanctuaries would keep their memories and legend spread their fame.

"In all the towns which were big, which God granted us to win from the Saracens, we built a church of Our Lady Saint Mary", proclaimed James the Conqueror proudly in his chronicle. ${ }^{3}$ However, the lack of either relics or images in this region of Western Christendom posed a tricky problem to the new settlers and their governors: How would they endow all those churches, not to mention the monasteries and chapels? The conversion of old mosques into churches involved in most cases a change of orientation, destruction of the mibrab and the introduction of religious images into its decoration and artefacts, as well as the consecration ceremony and the obligatory dedication to the Virgin, Saviour or a particular Christian saint. ${ }^{4}$ In fact, symbolic motives were at least as important as practical ones for converting Valencian mosques into churches even in areas where parishioners were scarce. ${ }^{5}$ Islamic buildings remained as useful structures for Christian worship

2 Burns, Robert I., The Crusader Kingdom of Valencia. Reconstruction on a Thirteenth-Century Frontier, Cambridge, MA 1967, pp. 2-3. For different, more recent and complementary views on the Valencian conquest and its aftermath cf. Torró, Josep, El naixement d'una colònia a la frontera medieval valenciana (I 238-I 276), Valencia I999; Martínez Sanmartín, Luis Pablo, Después de la conquista: consolidación de la Iglesia en tierras valencianas in: La luz de las imágenes I: La Iglesia valentina en su historia, Eds. Benito Domenech, Fernando and Sancho Andreu, Jaime, Valencia 1999, pp. 45-67.

3 Llibre dels fets del rei en Jaume, Ed. Bruguera, Jordi (Barcino, Els Nostres Clàssics, B I I), Barcelona I99I, chapter 450, pp. 326-327.

4 Harris, Julie A., Mosque to church conversions in the Spanish Reconquest in: Medieval Encounters 3, 2 (1997), pp. I 58-I72.

5 Burns, Robert I., The Significance of the Frontier in the Middle Ages, in: Medieval Frontier Societies, Eds. Bartlett, Robert and Mackay, Angus, Oxford I989, p. 326. 
for a long time, but aniconic interiors with Arabic inscriptions had to be furnished with painted or sculpted images. ${ }^{6}$

Later on, there came relics. King Louis IX of France gifted a thorn from Christ's Crown to Valencia cathedral in I 259; many years later, in I437, the Holy Grail was offered as security for a loan by king Alfonso V of Aragon to the same church's treasury, together with some other pieces from the royal chapel of the Aragonese kings. After many generations, Valencia cathedral could be proud of the rich treasure in its reliquary, augmented by the donations of kings and queens of Aragon, of cardinals, and of two Valencian popes from the Borgia family, Callixtus III ( $1455-1458)$ and Alexander VI (I 492-I 503). It attracted the local faithful and pilgrims on occasion of the public exhibition of these sacra pignora. ${ }^{7}$

Images, on the other hand, could be produced on Valencian soil or easily imported from other Christian territories or from across the Mediterranean. Both pathways were arguably open and explored, bearing in mind legal measures taken by King James I to control image making in the new kingdom. Among the 'Fori et Consuetudines Valentie', signed by James I in I27I, appears a legal restriction on sculptures and images: "Neither sculptures nor images of God or the Saints may be shaped nor made, nor even painted openly in market places, nor should they be offered nor brought for sale in market places. And whoever would do so must pay a penalty of twenty shillings". Although written sources have recorded the names of painters and different artists working in Valencia and other centres immediately after the conquest, it is doubtful they were able to produce refined Christian imagery - at least, not before the last quarter of the i 4 th century if we consider works and known documents on painting and sculpture from

6 Serra Desfilis, Amadeo, An Embarrassing Legacy and a Booty of Luxury. Christian Attitudes towards Islamic Art in the Medieval Kingdom of Valencia, in: Global Encounters, European Identities, Eds. Harris, Mary, Agnarsdóttir, Anna and Lévai, Csaba, (Cliohres.net and Pisa University Press), Pisa 2010, pp. 77-91, here 83-84.

7 Gavara, Juan Jesús, Mira, Eduard and Navarro, Miguel, Reliquias y relicarios en la expansión mediterránea de la Corona de Aragón: el Tesoro de la Catedral de Valencia, Valencia 1998 for a catalogue and a history of the Valencia cathedral treasure. On the exhibition of relics for public worship cf. Chabás Llorens, Roque, La exposición de las reliquias de la Catedral, in: Teixidor, Josef, Antigüedades de Valencia, Valencia r 895, vol. II, pp. 395-40 I.

8 Furs de València, Vol. II, Eds. Colón, Germà and Garcia, Arcadi (Els nostres clàssics Barcino Aro5), Barcelona I970, p. I 23. 
the first hundred years after the James I's conquest. ${ }^{9}$ The king wanted to prevent the sale of religious images in public places and, more broadly, to exercise control over the acquisition of icons for use in Christian worship for as long as there were not local workshops to meet the unquantifiable, yet urgent, demand. ${ }^{10}$ There may also have been concern that the widespread creation of icons could diminish their sacred aura, and even a desire to avoid conflict in a multi-confessional community, where Jews, Christians and Muslims had to coexist. ${ }^{\text {II }}$ It is likely that James I and his counsellors had imagined shops selling Marian icons, images of Christ and the saints like the one illuminated in one of the Cantigas codex commissioned by his son-in-law, Alfonso X, king of Castile and Leon, where a monk purchases a miraculous painting of the Virgin in the Holy Land (Ill. I03). ${ }^{\mathrm{I}}$ This reconstruction tends to confirm our knowledge about the origin of a significant number of well-documented paintings and sculptures, some of them still preserved as cult images, namely Our Lady of El Puig, Our Lady of Grace in Saint Augustine parish church (a former friary) and Christ Crucified, from the parish church of the Saviour.

Legends about the finding of cult images of the Virgin and child, painted or sculpted soon after Christian conquest, or allegedly related to King James I, raise difficult questions about their early worship across Valencian territory. ${ }^{\mathrm{I}}$ Rather than tell us historical truth, narratives about the

9 José i Pitarch, Antoni, Les arts plàstiques: l'escultura i la pintura gòtiques, in: Història de l'art al País Valencià I, Eds. Llobregat, Enric and Yvars, JoséFrancisco, Valencia 1986, pp. I65-239, especially, pp. I65-170; Documents de la pintura valenciana medieval i moderna I ( 238 -I 400), Eds. Company, Ximo et alii (Fonts històriques valencianes I9), Valencia 2005.

Io José i Pitarch, Antoni, Les arts in: Història del País Valencià, 2: De la conquesta a la federació hispànica, Ed. Belenguer, Ernest et alii, Barcelona I989, pp. 479-480.

I I Falomir Faus, Miguel, Arte en Valencia, I472-I 522, Valencia I 996, pp. 5 I-52.

I 2 San Lorenzo de El Escorial, Biblioteca del Real Monasterio, Códice Rico, T-I-I, cantiga 9, f. I 7 r.

I 3 Almarche Vázquez, Francisco, Primitivas pinturas de la "Mare de Deu" o Santa María, en Valencia, in: Archivo de Arte Valenciano IX (1923), pp. 25-40; Sánchez Gozalbo, Ángel, Imágenes de Madona Santa Maria. Notas para un inventario en las comarcas de Morella, el Maestrazgo, La Plana y Segorbe, in: Boletín de la Sociedad Castellonense de Cultura XXV (1949), pp. 448-492; Catalá Gorgues, Miguel Ángel, Escultura medieval, in: L'Edat mitjana: el gòtic (Història de l'art valencià 2, Biblioteca Valenciana, Consorci d'editors valencians), Ed. Aguilera Cerni, Vicente, Valencia I988, pp. 91-I 39, here 93-98; Blaya Estrada, Nuria, El icono que se esconde tras el icono de Nuestra Señora 
origins of these icons claim largely a miraculous discovery, with supernatural agency, and eventually a royal donation to public worship. As far as we can tell from the original appearance of these images, often after conservation processes, we are inclined to confirm a Northern provenance, from Catalonia or Aragon, or alternatively a generic adscription to a figurative lingua franca, a particular blend of principles of Byzantine art with Western features, regardless of the geographical origin of the artists involved in the painting. ${ }^{\text {I4 }}$ Nevertheless, legends about their origins served to legitimize the cult of the icons and confirmed their capacity to perform miracles in the context of the Christian conquest of the new kingdom of Valencia. Moreover, they attracted the devotion of Christian settlers and travellers to shrines without relics or even without any reputation as sanctuaries of pilgrimage or more popular worship.

\section{Sanctuaries mentioned in holy portolan charts}

An interesting group of such images was venerated in coastal shrines, in spite of the marshy and unprotected coastal environment. Sites like the church of Saint Mary of the Sea near Valencia harbour, or sanctuaries such as Saint Mary of El Puig, and the shrine devoted to the Virgin in Cullera castle, functioned both as reference points for those travelling along the Mediterranean coast, and as places of worship. They probably served as landmarks of the new Christian kingdom not only for local settlers but also for merchants, sailors and all kind of seaborne travellers. On the other hand,

de Gracia, in: Ars Longa, Cuadernos de arte 7-8 (1996-1997), pp. I85-193; Blaya Estrada, Nuria, La Mare de Déu de Montolivet. Aproximación a los iconos valencianos, in: Archivo de Arte Valenciano LXXVI (1995), pp. i i 8I 24; ead., Nuevos datos acerca de la presencia de iconos postbizantinos en el ámbito mediterráneo, in: Archivo de Arte Valenciano LXXIX (I998), pp. 5-9; ead., Oriente en Occidente. Antiguos iconos valencianos, Valencia 2000; see also Español Bertran, Francesca, Les imatges marianes: prototips, rèpliques i devoció, in: Lambard: Estudis d'art medieval is (2002-2003), pp. 87-I Io.

I4 Belting, Hans, Die Reaktion der Kunst des I 3. Jahrhunderts auf den Import von Reliquien und Ikonen, in: Il Medio Oriente e l'Occidente nell'Arte del XIII secolo (Atti del XXIV Congresso Internazionale di Storia dell'Arte 2), Bologna I982, pp. 35-54. In a broader way, see the review by Tsamakda, Vasiliki, Kunstimport aus Byzanz, in: Wege nach Byzanz, Eds. Fourlas, Benjamin and Tsamakda, Vasiliki, Mainz 20I I, pp. 88-99 on the importation of works of art in Western Europe. 
stories about their origins were part of a narrative of the Christian conquest, involving miraculous events and the punishment of Muslim or Jewish foes. Icons of the Virgin were interwoven in accounts of James I as conqueror and founder of the new Christian kingdom of Valencia, and the monarchy maintained a particular attachment to these shrines, fostering their role as local pilgrimage centres. If we consider a source like the Italian 'Sante Parole' of the fourteenth century, only Peñíscola, El Puig and Santa María del Mar are mentioned as noteworthy sanctuaries on the Valencian coast. ${ }^{15}$ Peñíscola was included, probably due to its dramatic natural setting on a small peninsula, on the northern coast of the new Kingdom of Valencia. It was a secure place to find shelter, with its natural port, and to obtain a water supply if needed. The fortress built by the Templar knights between I 292 and I 307 was certainly a stronghold of Christian dominion and a reference point for those seafarers travelling along the coast (Ill. 104). Nevertheless, only a modest parish church devoted to the Virgin and a more impressive chapel in the castle, transferred to the Valencian order of Saint Mary of Montesa since I 3 I7, served as places of worship, although unadorned by famous icons or relics, despite their magnificent aspect from the sea. ${ }^{16}$ Only the legend of the miraculous discovery of Our Lady of the Ermitaña in Peñiscola, referring to a sculpted image about 50 centimetres high, and dating from fourteenth century, could also help to explain its mention in holy portolan charts, but nothing has remained from the medieval shrine - not even the original icon, which is now lost. ${ }^{17}$ It seems probable that the decision of Pope Benedict

is Bacci, Michele, Portolano sacro. Santuari e immagini sacre lungo le rotte di navigazione del Mediterraneo tra tardo Medioevo e prima età moderna, in: The Miraculous Image in the Late Middle Ages and Renaissance. Papers from a conference held at the Accademia di Danimarca in collaboration with the Bibliotheca Hertziana, Rome, 3 I May-2 ${ }^{\text {nd }}$ June 2003, Ed. Thunø, Erik and Wolf, Gerhard, Roma 2004, pp. 223-248, here 248.

I6 Simó Castillo, Juan Bautista, El Castillo Templario Pontificio de Peñíscola, Barcelona I994; Zaragozá Catalán, Arturo, Arquitectura gótica valenciana, Valencia 2000, pp. 46-49; Navarro Benito, Myriam, Los castillos de la Orden de Montesa en la Baja Edad Media valenciana, Alicante 200I, pp. I45-I64, on the castle; Zaragozá Catalán, Arturo and Gil Saura, Yolanda, La Iglesia Parroquial de Peñiscola, in: La llum de les imatges: Paisatges sagrats, Valencia 2005, pp. I43-I I, regarding the parish church of Saint Mary.

I7 Gil Saura, Yolanda, Arquitectura barroca en Castellón, Castellón 2004, pp. 406-407. For the legend, cf. Matheu, Jaime, Novena Consagrada a Nuestra Señora Ermitana, precedida de una pequeña reseña histórica de la ciudad y su patrona, Valencia i786. 
XIII to establish what remained of the pontifical court in Peñiscola (I4 I 5I 422) contributed to maintaining its relevance no less than the busy wool export trade with Tuscany in the early fifteenth century.

Anyone sailing southbound from Valencia would have noticed the Cape of Cullera, a traditional reference point for navigation whose lighthouse still marks the southern limit of the gulf of Valencia. The castle was built on the arched mountain of Les Rabosses, which rises between the cape and the mouth of the river Xuquer. James I decided to share this strategic vantage point with the military order of Saint John of the Hospital in I 240. ${ }^{\mathrm{I}}$ Sources attest the worship of Saint Mary in Cullera castle since I 3 I I and the governing council of Valencia gave 500 sous to finance works in progress in the fortress and "in regard to a consecrated church which is in the castle" in $1393 .{ }^{19}$ A gothic sculpture of Saint Mary and the Child, dating from the second half of the fourteenth century or early fifteenth century, still presides over the chapel and is the object of special devotion in Cullera, but it is likely that her cult developed later than the composition of the 'Sante Parole'. ${ }^{20}$

This source refers instead to Saint Mary of the Sea (Santa Maria della Mare di Valenza) and this was the dedication of the parish church built in el Grao, the coastal borough of Valencia, the city being two miles inland from the coast. ${ }^{21}$ In Villa nova maris Valentie, at least since I 249, there has been a church benefitting from the legacies of the faithful, and which was probably popular among sailors, fishermen and merchantmen frequenting Valencia harbour. However, there is no record of an image of particular devotion prior to the legendary arrival of the Crucifix appearing from the sea around I4I I-I 4 I7, and linked to the prominent figure of Saint Vincent Ferrer. According to one of his sermons, this Crucifix should be identified with the one profaned by rabbi Moses Abenabes, who reportedly inflicted

I 8 Arciniega García, Luis, Sistemas de defensa en Cullera: Castillo, murallas y torres, Cullera 2003.

I9 Valencia, Archivo Histórico Municipal, Manual de Consells, A-2o, f. I I4v, August I4, I 393, quoted by Vidal Beltrán, Eliseo, Valencia en la época de Juan I, Valencia I974, p. 234.

20 Giner, Francisco, La Mare de Déu del castell de Cullera. Estudio histórico, Cullera 1976, especially, pp. 31-59; Giner Perepérez, Francesc, La Mare de Déu del castell de Cullera. Estudio histórico, in: III Jornades d'Estudis de Cullera, Benicull de Xúquer 2000, pp. 543-566.

2 I Guiral Hadziiossif, Jacqueline, Valence, porte mediterranéen au $X V^{e}$ siècle (I410-I 525), Paris I986; Boira, Josep Vicent and Serra, Amadeo, El Grau de València. La construcció d'un espai urbà, Valencia 1994, pp. 9-44. 
tortures and punishments on the image, similar to those of Christ's Passion, before throwing it in the river. ${ }^{22}$

\section{A cathedral in honour of Saint Mary}

There was concern to have a richly-fashioned cathedral, and the first stone was laid on June 22, I 262, putting an end to a short period of Christian use of the main mosque in the capital city. The new church, dedicated to Our Lady Saint Mary and elevated to the status of cathedral by Pope Gregory IX, was bound to become the main stage of liturgy and of several public functions for Christian settlers after the conquest. In sharp contrast with the mosques converted to cathedrals in Cordoba or Seville, the new gothic building in Valencia advanced at a rapid pace, probably due to the symbolic requirement for a "more imposing, more aggressively Christian" temple, in Robert I. Burns' words. ${ }^{23}$ Even as the cathedral was being installed in the mosque, a special privilege was obtained from Pope Alexander IV (I 257) allowing forty days' indulgence to those who, at the four great festivities of the Virgin, should visit the "church of Valencia established in honour of Blessed Mary the Virgin”. ${ }^{24}$

While the converted mosque could function as a cathedral for some years, Christian images were absolutely necessary in order to consecrate the sanctuary. King James I endowed a Marian icon of Our Lady of the See (Nuestra Señora de la Seo), which rested on the high altar until a new silver retablo occupied its place by the mid-fourteenth century. The declaration at the papal court of one of the witnesses to the consecration, John the Painter, of Teruel, confirms that after the purification of the mosque, an altar was built and a cult image was

22 Arciniega García, Luis, La Passio Imaginis y la adaptativa militancia apologética de las imágenes en la Edad Media y Moderna a través del caso valenciano in: Ars Longa. Cuadernos de arte 2 I (20I 2), pp. 7 I-94, especially 88-89, which quotes the original sources of this legend.

23 Burns (note 2), pp. I7-2 I.

24 Valencia, Archive of the Cathedral, perg. I.326 (March 24, I 257): cupientes igitur ut Ecclesia Valentina que in honore beate Marie Virginis constructa esse dinoscitur congruis honoribus frequentetur, omnibus vere penitentibus etconfessis qui ecclesiam ipsam in Quattuor festivitatibus ipsius Virginis et in Octavis ipsarum visitaverint annuatim de omnipotentis dei misericordia [...] Quadraginta dies de iniunctis sibi penitentiis misericorditer relaxamus. Cf. Burns (note 2), pp. I 8-20. 
installed to celebrate the first Holy Mass on October 9, I $238 .{ }^{25}$ Unfortunately this panel is only known from old photographs, since it disappeared during the Spanish Civil War (Ill. Io5). Before that, the eighteenth century historian José Teixidor was able to copy the Latin inscription under the painting: Obtulit buic Urbi post barbara colle subactal Hanc primam Sacrae Virginis effigiem/ Rex super insignis Regumque norma Jacobus. I Mente reverenti prospice quisquis aedes [Offered to this city, after having conquered the enemies, this first image of the Holy Virgin, the illustrious king and example for other kings, James, Oh whoever you are behold it with respect]. ${ }^{26}$ The original appearance of this icon included a figure of King James I and a queen but José Sanchis Sivera believed it was probably not very different from the miniature in the frontispiece of 'Liber instrumentorum' manuscript (circa I4 IO) (Ill. 106). ${ }^{27}$ Authors from the eighteenth century identify without doubt King James and Queen Yolanthe of Hungary in half relief, probably added to the original icon. The king indeed confessed in his chronicle to having vowed to Our Lady Mary during a three-day-storm to come back before her altar in Valencia. ${ }^{28}$ Nevertheless, this venerable icon was displaced by a new silver Madonna and Child and a whole retablo in silver commissioned from the royal silversmith Pere Bernés in the second half of the fourteenth century. According to the customs followed in the early sixteenth century, the image of the Virgin presided over processions in the cathedral on the occasion of major liturgical feasts and it would be reasonable to suppose that the old panel could also have had this ritual function in previous times. ${ }^{29}$

The arrival of unam de spinis sacrosancte corone domini nostri Iesuchristi offered by King Louis IX of France in I 256 was a special occasion for a reborn cathedral which lacked relics, and soon prompted a pictorial decoration of the

25 Quod illud fuit primum altare quod fuit constructum Valentie intra muros. Cf. Castell Maiques, Vicente, Proceso sobre la ordenación de la Iglesia valentina entre los arzobispos de Toledo, Rodrigo Jiménez de Rada y de Tarragona, Pedro de Albalat (I 238-i 246), vol. I, Valencia I996, pp. 4I9-420.

26 Teixidor, Josef, Antigüedades de Valencia, Ed. Chabás, Roque, Valencia i 895, I, pp. 220-22 I; Sanchis Sivera, José, La catedral de Valencia. Guía histórica y artística, Valencia I909, pp. I62 and 25I; Almarche Vázquez (note I3), pp. $25-40$, here $26-29$.

27 Valencia, Biblioteca Capitular, ms. I62, f. 6r.

28 Teixidor (note 26), I, pp. 220-22 I.

29 La Consueta de la Seu de València dels segles XVI-XVII. Estudi i edició del Ms. 405 de l'ACV, Eds. Martí Mestre, Joaquim and Serra Estellés, Xavier (Monumenta Archivorum Valentina X, Facultad de Teología "San Vicente Ferrer"), Valencia 2009. 
secret chamber where it was kept. ${ }^{30}$ The wall paintings representing the Flagellation, on one side, and a Mocking Christ between the figures of Caiaphas and Pilate, on the other, flank the small receptacle containing this precious relic under an image of the Crown of Thorns held by a pair of angels (Ill. I07). This secret chamber could only be reached via a ladder from the old sacristy and therefore the audience for these paintings must have been limited from the outset. And yet the whole decorative programme bears witness to a particular ambition to preserve the Holy Thorn within a figurative context alluding to the Passion of Christ, produced by an unknown artist acquainted with European gothic models. ${ }^{3 \mathrm{I}}$ These paintings, covering the front of one of the walls, reflect the activity of a workshop aware of the effects of colour, gilded architectural frameworks and sophisticated narrative scenes, enriched with tituli and lively characters, used in order to compose a moving mural of the Passion in a late thirteenth century style.

A later surge of activity coincided with the founding of the new gothic building. Bishop Andreu d'Albalat dedicated one of the central chapels of the ambulatory to Passio Imaginis in I 262, later furnished with a retablo narrating the story of the Beirut Crucifix. Between this chapel and the one dedicated to Saint James the same bishop laid the first cornerstone, with a solemn inscription commemorating the start of the new Christian cathedral..$^{32}$ On the other hand, a panel of Christ as Man of Sorrows preserved before 1936 in Valencian Diocesan Museum, showed an Italianate style from fourteenth century and it could be possibly related to the original cult of Passio Imaginis. ${ }^{33}$ All these

30 Rodrigo Lizondo, Mateu, Catàleg dels pergamins de l'Arxiu de la catedral de Valencia ( $2^{\text {a }}$ Sèrie), Valencia 2012 , p. 20.

3 I Catalá Gorgues, Miguel Ángel, La pintura d'estil gòtic-lineal i la influencia catalana en València, in: L'Edat Mitjana. El gòtic, Ed. Aguilera Cerni, Vicente (Història de l'art valencià 2), Valencia I988, pp. I43-I8I, here I46-I6I.

32 It has not been preserved since the eighteenth century refurbishment of the cathedral but it is known through previous transcriptions, cf. Teixidor (note 26), I, pp. $22 \mathrm{I}-223$.

33 Meiss, Millard, Italian Style in Catalonia and a Fourteenth Century Catalan Workshop, in: Journal of the Walters Art Gallery 4 (I94I), pp. 45-86, here 6I-62 and figure I8. This author classified this panel as "Sienese, late XIVth century" and related its style to both Andrea Vanni and Andrea di Bartolo. Cf. Barberá Santemans, Antonio, Catálogo descriptivo de los objetos conservados en el Museo Arqueológico Diocesano de Valencia, Valencia I923. On the relations between Imago Pietatis and Crucifixion, cf. Belting, Hans, Das Bild und sein Publikum im Mittelalter. Form und Funktion früher Bildtafeln der Passion, Berlin i 98 I, pp. 263-276. 
circumstances make it more likely that this dedication corresponded to this ceremony, rather than to the worship of a particular image of the Crucifix, an object of its own cult in a parish church not far from the cathedral. The retablo is lost and only known from a seventeenth century engraved illustration of the work Identidad de la imagen del S. Christo de S. Salvador de Valencia (Valencia, I672), but it is difficult to accept a chronology dating back to the second half of the thirteenth century. ${ }^{34}$ The Crucifix from San Salvador parish church was soon identified with the sacred image from Beirut linked to certain miraculous events. ${ }^{35}$ Elsewhere, there was a significant connection between the Passio imaginis and the consecration of churches; this was particularly interesting in lands like Valencia, where a psychological boundary was always present in the frameworks within which Jews, Muslims and Christians coexisted. Dominican hagiographers, for instance Jacopo della Voragine, put an emphasis on this narrative about the Beirut crucifix profaned by the Jews, the miracle, and their conversion. ${ }^{36}$ In addition, a chapel in the cathedral was dedicated to Sant Bult, clearly adapted from the Volto Santo in Lucca. Its story tells of how a mason found the image in a water well, in the Xerea quarter of the town, where it soon became popular and gave rise to a local festival still celebrated once a year.

A canvas with the iconography of a Longitudo Christi has survived to the present in good condition, and is preceded by a legend about its miraculous origin, although its chapel was transformed into an altar because of the eighteenth century works in the cathedral. ${ }^{37}$ A pious tradition tells about a

34 Teixidor (note 26), I, p. 223; Sanchis Sivera (note 26), pp. 3I4-3 I 5; Arciniega García (note 22), pp. 76-8I. It is likely that the retablo could be painted on occasion of the establishment of a new benefice by Ramón de Castelló in I 364 , cf. Sanchis Sivera (note 26), p. 495 .

35 Arciniega García (note 22).

36 Cf. Bacci, Michele, Quel bello miracolo onde si fa la festa del santo Salvatore. Studio sulle metamorfosi di una leggenda, in: Santa Croce e Santo Volto: Contributi allo studio dell'origine e della fortuna del culto del Salvatore (secoli IX-XV), Ed. Rossetti, Gabriella, Pisa 2002, pp. I-86; cf. Espí Forcén, Carlos, Recrucificando a Cristo. Los judíos de la Passio Imaginis en isla de Mallorca, Murcia 2009, about this motif and its connections to anti-semitism in a neighbour territory of the Crown of Aragón.

37 Llompart, Gabriel, 'Longitudo Christi Salvatoris'. Una aportación al conocimiento de la piedad catalana medieval, in: Analecta Sacra Tarraconensia 40 (1968), pp. 93-1 I5, also in Llompart, Gabriel, Entre la historia, el arte y el folklore: Folklore de Mallorca, Folklore de Europa, Mallorca I984, pp. $225-$ 248. Blaya Estrada, Oriente en Occidente (note I3), pp. 2 I 2-2 I 5; Ruiz i Quesada, Francesc and Montolio Torán, David, Salvador Mundi, in: La llum de 
Portuguese pilgrim who wanted to take a measurement of the Holy Sepulchre. A Turk accompanying him laid out his turban to measure the tomb and suddenly the image of Christ was stamped on the fabric. As a result, the Turk converted to Christianity and received baptism from one of the Franciscan wardens of the Holy Sepulchre. The Portuguese traveller, upon returning to his homeland, offered the icon to Queen Eleanor, wife of Peter IV of Aragon and infante of Portugal, who in turn donated it to Valencia cathedral. ${ }^{38}$ This fourteenth century icon appears related to similar images kept in Barcelona, Mallorca (baptism chapel in the parish church of Santa Eulalia), Castellón (Fine Arts Museum) or Mora de Rubielos, all substantiating a special widespread presence throughout the lands of the Crown of Aragon in the Late Middle Ages. ${ }^{39}$

We can probably accept that these images, related to holy relics, were an effort to make visible the consecration of the most venerated church of the Valencian diocese, but they also represent an approach to popular devotion in a frontier kingdom: a cumulative effort to provide the faithful with tangible remains of the Christ and the Virgin, and spiritual benefits, combined with the aim of affirming the Christian triumph over Muslims and Jews.

\section{Our Lady of Grace in the church of Saint Augustine}

Valencia's Augustinian priory was established by I 28 I - or a few years before, although it is not mentioned in any wills earlier than this. Among gifts received by St. Augustine's there was a service ornament from King Peter III. Before I 298, the priory church had become the centre for such brotherhoods as the blacksmiths and silversmiths. A document of December I 300 allowed the Augustinian friary to increase its holdings, free from royal

les imatges: Espais de Llum (expos. Borriana, Vila-Real, Castelló 2008-2009), Eds. Sanahuja, Jaime, Saborit, Pere and Montolío, David, Valencia 2008, pp. $2 \mathrm{IO}-2 \mathrm{I} 3$.

38 Sanchis Sivera (note 26), pp. 288-292. The text in the book reads: Ego sum via, veritas et vita. Ego sum qui sum et consilium non est cum impiis. However, an inscription on the chapel remembered a late date of donation to the cathedral (I 437).

39 Blaya Estrada, Oriente en Occidente (note I3), p. 38 and 2 I 2-2 I 3. The original icon was transferred to a decorative panel with two doors and underwent successive restorations in 1765 and 1998 . 
taxation, in what has been interpreted as the beginning of a new building plan. $^{40}$

According to tradition, an angel presented the Marian icon when he came across two friars from Saint Augustine's on their way to commission a new painting in Valencia. ${ }^{4 \mathrm{I}}$ This legend makes the icon, still preserved in good condition in the same church since its arrival in Valencia, an acheiropoietic image. Modern authors have insisted on a stylistic attribution to an italogothic workshop (maniera greca) proposing a chronology starting in the fourteenth century (Ill. I08)..$^{42}$ Nuria Blaya identifies in this panel a blend of late Byzantine tradition and some elements of Trecento painting. This author identifies the archetype in the Virgin donated by saint Arseny to the monastery founded in Konevets Island in the Ladoga Lake around I 393 and has suggested some analogies with the work of Greek artists painting for Latin patrons either in Venice or in some other Mediterranean centre. Nuria Blaya points to the Sterbini diptych (Rome, Palazzo Venezia) and establishes some links between the Valencian icon and the panel attributed to the same painter now in Messina (Museo Regionale), where Virgin and Child are flanked by Saint Agatha and Saint Bartholomew. More widely, this author sees connections with the Madonna and Child attributed to the Master of Baltimore at Walters Art Gallery. ${ }^{43}$

Public worship of this icon was soon widespread in Valencia: Our Lady of Grace became the foremost protector of Valencia, and was celebrated in processions and public ceremonies praying for rain or for the end of the

40 Burns (note 2), pp. 209-2 I 2.

4I Jordán, Jaime, Historia de la provincia de la Corona de Aragón de la sagrada orden de los Ermitaños de Nuestro Padre San Agustín, Valencia 1704, p. I95; see also, for a modern version of the pious legend, Belda, Miguel, Memoria histórica de la milagrosa imagen de Nuestra Señora de Gracia, Valencia i9 I 5.

42 Blaya Estrada, El icono (note I 3); Blaya Estrada, Nuria, La tabla de Nuestra Señora de Gracia y otros iconos marianos en Valencia, in: El icono de Nuestra Señora de Gracia, Eds. Benito Goerlich, Daniel et alii, Valencia 2007, pp. $57-72$.

43 Meiss (note 33), pp. 45-87; Blaya Estrada, La tabla (note 42), pp. 66-67. On this itinerant Greek painter working for Latin patrons in Venice and its Adriatic dominions, cf. Corrie, Rebecca W., The Polesden Lacey Triptych and the Sterbini Diptych: A Greek Painter between East and West, in: Proceedings of the $2 \mathrm{I}^{\text {st }}$ International Congress of Byzantine Studies (London, $2 \mathrm{I}-26 \mathrm{Au}$ gust, 2006), London 2006, III, pp. 47-48, and Bacci, Michele, Prattica artistica e scambi culturali nel Levante dopo le crociate, in: Medioevo: Le officine (Atti del convegno internazionale di studi, Parma, 22-29 settembre 2009), Ed. Quintavalle, Arturo Carlo, Milano 2010, pp. 494-5 I0, here 494-495. 
plague, as well as in the main festival of Christ's Incarnation, from the fourteenth century. ${ }^{44} \mathrm{~A}$ form of appropriation by Henry II Trastamara took place, when the Castilian king ordered the building of a new chapel in the convent in 1370 , endowing it with a sum of 3000 maravedis in 1372 ; a privilege confirmed the royal protection by the Catholic Monarchs, Isabella and Ferdinand, in $\mathrm{I}_{472}$, but the chapel was rebuilt twice, the last time in $1750-$ 1754. The foundation of this royal chapel by the major ally of Peter IV of Aragon during the war against Peter I of Castile (I 356-I 369), who twice brought the Castilian army to the walls of Valencia, in I 363 and I 364 , could hardly have been unrelated to a desire to confirm Marian protection of the Trastamara dynasty. ${ }^{45}$

Significantly enough, public worship and processions started after the building of the new chapel: in I 373 municipal counsellors summoned a general procession from the cathedral to the 'chapel of Our Lady of Grace', to be celebrated, for the first time, on March 26 th $^{46}$ One and a half years later, the local authorities called upon the citizens of Valencia to participate, on October 28 I 373, in another procession against plague, drought and illness, by going "before the altar of Our Lady of Grace". ${ }^{47}$ When Valencia was spared in an earthquake of $\mathrm{I} 396$, it was attributed to the intercession of the icon and consequently the miracle was celebrated with another public procession. ${ }^{48}$ On these special occasions, communal worship of this pictorial icon of the Virgin made manifest a steadily-growing popular devotion,

44 Guiral, Jacqueline, L'evolution du paysage urbain à Valencia du XIII au XVI siècle, in: La ciudad hispánica durante los siglos XIII al XVI. (Actas del coloquio celebrado en Sevilla y La Rábida del I4 al i 9 de septiembre de I98I), Eds. Sáez, Emilio, Segura Graiño, Cristina and Cantera Montenegro, Margarita, vol. II, Madrid I985, pp. I.58 I-I.610, here 1.603-1.606; Narbona Vizcaíno, Rafael, Memorias de la Ciudad. Ceremonias, creencias y costumbres en la historia de Valencia (Ajuntament de València, Estudis I9), Valencia 2003, pp. 69-83.

45 Benito Goerlich, Daniel, El Templo de San Agustín de Valencia, de monasterio a parroquial, in: El icono de Nuestra Señora de Gracia de Valencia, Valencia 2007, pp. I I-52; Ruiz i Quesada, Francesc, Els primers Trastàmares. La legitimació mariana d'un llinatge, in: Capitula facta et firmata: Inquietuds artístiques en el quatre-cents, Ed. Terés i Tomàs, Maria Rosa, Valls 2009, pp. 7I-I I 2, especially pp. 7I-73 and 79-80.

46 Valencia, Archivo Historico Municipal, Manual de Consells, A-ı6, f. I4 Ir; March 23, I373.

47 Ibid., f. 230v, October 27, I 374.

48 Ibid., A-2 I, f. I 55 r, December I5, I 397. 
at least until the new cult of Our Lady of the Forsaken (Nuestra Señora de los Desamparados) took its place.

In the sixteenth century, the icon appeared embedded in a retablo of a Marian cycle in a common Valencian fashion, attributed to Joan de Joanes: a cult image painted or sculpted, and a narrative with the Seven Joys of the life of the Virgin. ${ }^{49}$ In his work Alphabetum Augustinianum Tomás de Herrera (Madrid, I644) refers to a chapel sub invocatione B. Mariae de Gratia where many faithful devoted meet quam de diversis mundipartibus confluunt. ${ }^{50}$

\section{The hill of the Virgin: El Puig de Santa Maria}

Prior to the siege of Valencia, in September I 237, Saint Peter Nolasco seems to have discovered an ancient icon of the Virgin, hidden long before by Christians fearing the Islamic invasion of the Iberian Peninsula; it was found by chance under a bell in the castle at El Puig (a Catalan word for hill) which defended the northern approaches to the city. ${ }^{\text {II }}$ Bells rang out in victory over Muslim foes. ${ }^{52}$ The name of the hill was promptly altered to Puig de Santa Maria (Hill of Saint Mary). It was here, before the altar of the Virgin and surrounded by his knights, that James made his vow never to return north until Valencia was conquered. During a critical battle, Christian knights

49 Samper Embiz, Vicente, Un retablo de la vida de la Virgen y algunas consideraciones sobre los Siete Gozos, in: Archivo de Arte Valenciano LXXIV (1993), pp. 33-43; Deurbergue, Maxime, The Visual Liturgy. Altarpiece Painting and Valencian Culture (I442-I I19), (Études Renaissantes), Turnhout 20I 2, pp. I 56-I66.

50 Ferri Chulio, Andrés de Sales, La Mare de Déu de Gràcia de la Parroquia de San Agustín de Valencia, in: El icono (note 45), pp. Io5-I 2 I, particularly pp. IO8-I IO.

5 I Molina, Tirso, El Monasterio de El Puig y su Virgen, Ed. Devesa, Juan, Valencia I968; Martínez, Francisco, Historia de la imagen sagrada de la Virgen del Puig reducida a una prudente crítica con que se comprueban todas sus maravillosas circunstancias, Valencia I 760.

52 The raids of Al-Mansur against Santiago de Compostela turned to Córdoba with the bells of churches as booty carried by Christian prisoners and bell towers were one of the first symbols of the Christian dominion established after the conquest. Muslim diplomat and poet Ibn-al-Abbar lamented the fall of Valencia in I 238 remarking how bells summoned Christians to churches from the same towers where the muezzin used to call the faithful to prayer at the mosques. Cf. Serra Desfilis (note 6), here p. 85. 
received decisive aid from Saint George, according to fourteenth century chronicles, but earlier sources attributed their victory to a direct Marian intervention. Our Lady of Victories does indeed appear at the top of Saint George altarpiece (London, Victoria and Albert Museum, circa I400-I4IO), while the central panel was divided between the battle scene of El Puig with King James and Saint George fighting side by side against the Islamic army, with the slaying of the dragon and the liberation of the princess in the lower part. ${ }^{53}$

El Puig de Santa Maria was the first important shrine established by the king in honour of the Virgin as protector of the realm he was conquering. Images of the Virgin were supposed to have been buried by Christians fleeing during times of persecution or war, and were later miraculously discovered. Felipe Guimerán compared the finding of the Marian icon with the hiding of the Tabernacle and the Ark of the Covenant by Jeremiah (II Macc. 2, 4-8), thus reinforcing the parallel between the Virgin and the Ark. ${ }^{54}$

In I29I, Pope Nicholas IV took the Mercedarian lands and houses in the Valencian kingdom under his protection. He made specific reference to El Puig, to the "houses, lands, and vines you have in the city and diocese of Valencia" and other "towns and castles". There were legacies for the shrine, too, in the wills of Valencian settlers." The relatively modest buildings first erected for the order of Our Lady of Mercy, chosen as guardians of the sanctuary by King James, fell into some disrepair during the next century. The family of Admiral Roger of Lauria, linked to the hero of the

53 Martínez Ferrando, Jesús Ernest, El Puig de Santa Maria. Una evocació de la reconquesta, El Puig 1995, on the battle and its significance for the conquest campaign; on the late medieval historiography and its use in figurative arts in the Crown of Aragon, cf. Serra Desfilis, Amadeo, Ab recont de grans gestes. Sobre les imatges de la història i de la llegenda en la pintura gótica de la Corona d'Aragó, in: Afers 4I (2002), pp. I 5-35; on the retablo itself, cf. Kauffmann, Claus Michael, The Altarpiece of Saint George from Valencia, in: Victoria and Albert Museum Yearbook 2 (1970), pp. 65-100; Miquel Juan, Matilde, El gótico internacional en la ciudad de Valencia. El retablo de San Jorge del Centenar de la Ploma, in: Goya 335 (20II), pp. I9I-2 I3; Serrano Coll, Marta, Falsas historias, proposiciones certeras. Dominio visual e imágenes persuasivas en el entorno áulico de la Corona de Aragón, in: Codex Aquilarensis (Cuadernos de Investigación del Monasterio de Santa María la Real) 27 (20I I), pp. I9I-2 I 2, here 204-208.

54 Guimerán, Felipe, Breve Historia de la Orden de Nuestra Señora de la Merced de cautivos Christianos y de algunos santos, y personas illustres della, Valencia I 59I, pp. I 20-I 24.

55 Burns (note 2), pp. 249-252. 
battle, Bernat Guillem d'Entença, by his second wife Saurina d'Entença, took over patronage of the monastery. Works were probably in progress around I 3 I 2, to judge by a legacy of 500 morabetins granted by admiral Roger of Lauria for this purpose. ${ }^{56}$ Lady Margaret of Lauria, countess of Terranova and the last of the patronal family, promoted the replacement and expansion of the first buildings around the year 1340 , including the church, the monastery, a small hospital and the old chapel of Saint George on the adjacent hill. ${ }^{57}$ In I 343, Margaret changed an earlier will (I 34I) and decided to be buried in El Puig church instead of in Santes Creus Cistercian abbey. ${ }^{58}$ She also ordered further building work on the chapel and the bell tower then under construction, ${ }^{59}$ and probably managed to confer a resemblance of the new temple on Santes Creus abbey church, with the intention of associating her family pantheon with the dynastic tombs of Peter III and James II, and the sepulchre of Admiral Roger of Lauria in the Cistercian monastery (Ill. I09). ${ }^{60}$

Testaments, legacies, and inscriptions bear witness to an early cult of the Marian icon from the mid-I 3 th century. ${ }^{61}$ An epitaph on the tomb of fray Raimon Albert (after I330) declares that the first master of the Order of Our Lady of Mercy to also be a priest had been buried ad domum Beatae Virginis Mariae de Podio, celebrate ad Apostolorum adventu. ${ }^{62}$ Certainly, the shrine had become a place of pilgrimage when Pope Benedict XIII issued a bull in 1407 , where, after remembering his frequent visits to the sanctuary, he declared:

cuius imaginem accepimus (prout praeteritorum gesta commemorant) Angelicis manibus elaboratam, eorumdemque ministerio, a loco santo Gethsemani, ubi Sacrum Corpus Marie iacuit, huiusmodi foelicissimo littore divinitus ad-

56 Gazulla, Faustino, El Puig de Santa María, in: III Congreso de Historia de la Corona de Aragón (Valencia, Julio de I923), Valencia I923, vol. 2, pp. 593654 , here 6i 4 .

57 For more on this chapel, built on the top of the hill, cf. Domínguez Rodrigo, Javier, La ermita de San Jorge de El Puig: arquitectura e iconografía, Valencia 2003.

58 Gazulla (note 56), p. 6is.

59 Domínguez Rodrigo, Javier, El Puig de Santa María: aproximación histórica y valoración crítica, Valencia I992, pp. I 43-I 49.

60 José i Pitarch (note I I), here p. 474.

6 I Gazulla (note 56), pp. 62 I-652.

62 Gazulla, Faustino, Sepulcros de Fray Pedro Amer y Fray Raimundo Albert en el Santuario de Nuestra Señora de El Puig, in: Archivo de Arte Valenciano IX (1923), pp. 3-17; cf. Molina (note 5 I), p. 37. 
lantam, ac summa populorum frequentia a primis saeculis undequaque confluentium indubitata fide veneratam. ${ }^{63}$

However, the first specific reference to the icon in written sources dates back to I 362, when an inventory of ornaments and jewellery preserved in the church mentions it among the objects of the magnificent church treasury. The great number of crowns, lamps and other jewels offered to the sanctuary are a symptom of the popularity and wide veneration of the icon. ${ }^{64}$ In $\mathrm{I} 448$, a visit describes more specifically a retablo, and in the corner, "an image of the Virgin, made of stone, of which it is said that it was found here in El Puig, when this land was conquered". ${ }^{65}$ Thirty years later, in I 478, an inventory mentions one image on the high altar and another icon, called the ancient one, close to the altar. ${ }^{66}$ It is doubtful that this second icon was the stone relief - as Gazulla took for granted - or the panel painting studied by Almarche Vázquez, but the latter disappeared after Spanish Civil War. ${ }^{67}$ Some authors perceive an echo of this icon in a sculpted capital of the church portal representing the Epiphany, which surely dates from the second half of the thirteenth century (Ill. I I 0$)^{68}$

Among the series of miracles collected by Felipe Guimerán it is worth noting the number of them related to sea travellers, beginning with the Marian intervention in aid of King James II, when he was about to sink during his voyage from Sicily to Valencia, or the sailors from Biscay rescued by the Virgin. ${ }^{69}$

Since the foundation of the church and the monastery, the protection of royal patrons held strong: even though official patronage was transferred to the Lauria-Entença family in the early fourteenth century, the memory of James I and the epic battle remained for centuries. His successors often visited the monastery, as James II did in I 296, with the aim of justifying the existence of royal lodgings at that time; and later, when Peter IV, son of Alfonso IV and Teresa d'Entença, and his wife Eleanor of Sicily stayed there

63 Gazulla (note 56), p. 602.

64 Ibid., p. 606, full text transcribed at pp. 652-654.

65 Barcelona, Archivo de la Corona de Aragón, Merced 26, fol. 2 I I, as quoted by Gazulla (note 56), p. 602. Item, al cantó del dit retaule una imatge de la Verge, de pedra, la qual se diu fonch trobada ací en lo Puig, quant foch la conquesta de aquesta terra.

66 Gazulla (note 56), pp. 608-609.

67 Almarche Vázquez (note I3), pp. 3 I-32.

68 Domínguez Rodrigo (note 59), pp. I I I-I I 2; Buchón Cuevas, Ana María, El Puig y su patrimonio escultórico, El Puig 2008.

69 Guimerán (note 54), pp. I43-1 54. 
for the birth of their daughter Eleanor. ${ }^{70}$ Two silver sculptures of King Peter IV and his wife flanking the Virgin, and two angels, were commissioned from the goldsmith Pere Bernés for the price of 2.667 sous. $^{71}$

The relief icon itself and its presumed origin have been the object of some discussion (Ill. I I I).$^{72}$ Mary sits on throne with the Child in her arms, flanked in the upper corners by two busts of angels with humeral veils. Standing on his Mother's knees, the infant Jesus moves dynamically toward Mary as if wanting to caress her face. The large dimensions of the slab (98 x 62 x I I.7 cm) and the material suggest a Mediterranean origin and almost exclude a provenance from Catalonia or Aragon, as was the case of the oldest sculptures of the Virgin still preserved in the kingdom of Valencia. ${ }^{73}$ Daniel Benito Goerlich identified a model for the El Puig Madonna in the relief icon of the Madonna Aniketos in the cappella Zeno in Saint Mark's in Venice, confirming thereby its Byzantine origin. ${ }^{74}$ This icon of Theotokos Aniketos (H ANIKHTO , reads the inscription) presents the same iconographical motif at an even larger scale ( 120 × $85 \mathrm{~cm}$ ) than the El Puig Madonna and has been frequently studied. ${ }^{75}$ However, stylistic differences are fairly significant: plasticity is greater in the curves in the modelling of the faces, hands, feet and heads of the figures, and the folds in the drapery appear more finelywrought in the Valencian relief, a feature almost neglected by the historiography of Byzantine relief icons. Compared to these, the El Puig stone relief is neatly framed by a rectangle and has retained some polychromy thanks to

70 Gazulla (note 56), pp. 652-653.

7I A price of I60 sous per silver mark gives a value of I 6.668 silver marks. Cf. Rubió i Lluch, Antoni, Documents per l'història de la cultura catalana migeval, II, Barcelona I92 I, p. I9I; Durán Cañameras, Félix, La escultura medieval en el Reino de Valencia, in: Anales del Centro de Cultura Valenciana XIII (1945), pp. I I7-I 27, here I 2 I.

72 Benito Goerlich, Daniel, Valencia y Murcia (La España gótica 4), Madrid I989, pp. 416-422; Domínguez Rodrigo (note 59), pp. 79-87; Buchón Cuevas (note 68), pp. I9-25.

73 Catalá Gorgues, Escultura medieval (note I 3), pp. 93-98.

74 Benito Goerlich (note 72), p. 42 I.

75 Lange, Reinhold, Die byzantinische Reliefikone, Recklinghausen i 964; Davis, Charles, Byzantine Relief Icons in Venice and along the Adriatic Coast: Orants and other images of the Mother of God, München 2006, p. 33, http://archiv. ub.uni-heidelberg.de/artdok/270/I/Davis_2006.pdf (last access 24/I2/20I3) offers a complete bibliographical survey on this Venetian relief. 
modern restorations, but it does not include any inscriptions. ${ }^{76}$ The victorious connotations of a Theotokos Aniketos were suitable for the El Puig Madonna, venerated in a sanctuary built on the same site where a resonant Christian triumph had occurred. Even the same idea of venerating stone and image in a visible unity connects El Puig with the Venetian model. Where legend supposed that the Aniketos had been hewn from the stone from which Moses miraculously drew water in the desert, ${ }^{77}$ the relief icon of El Puig was believed to have been made by angels from the lid of Mary's tomb, and the legend claimed that its cult was begun in the time of the Apostles. ${ }^{78}$

Legends aside, on the grounds of formal analysis and the historical events, it seems reasonable to attribute an Italian origin to the El Puig Madonna. This Valencian image should be placed in a wider context which includes not only Byzantine stone reliefs reaching the Adriatic coast, and Venetian works, but also Italian copies or derivations from middle or late Byzantine models. Rather than thinking necessarily of booty from the Fourth Crusade, we should consider the origins of Roger de Lauria (I 245-I305) in southern Italy, and that his second wife, Saurina d'Entença, devoted to El Puig, sent fray Pedro García to Italy soon after Roger's death to deal with some affairs of interest for the monastery. ${ }^{79}$ The frequent journeys and exchanges between the Crown of Aragon and Sicily under James II's reign, may well have encouraged and enabled the patrons to import a large stone Marian icon directly from the Adriatic coast or even Sicily, where similar objects remain in significant number. ${ }^{80}$

76 On modern restorations to renew the traditional polychromy of the icon, cf. Domínguez Rodrigo (note 59), pp. 79-87; for discussion of the significance of inscriptions and frames accompanying relief icons, cf. Davis (note 75), pp. 5-6, and Weinryb, Ittai, The inscribed image: negotiating sculpture on the coast of the Adriatic Sea, in: Word and Image 27/3 (20I I), pp. 322-333.

77 Belting, Hans, Likeness and Presence. A History of the Image before the Era of Art, Chicago 1994, pp. 199-200.

78 The bell in which the image of the Virgin was hidden was decorated with an inscription explaining its miraculous provenance: ab Angelis in lapide sepulchri tui dedolata, et ab eis asportata; ac Apostolorum adventu decorata. Cf. Boyl, Francisco, Nuestra Señora del Puche. Cámara angelical de María Santissima. Patrona de la insigne ciudad y reyno de Valencia, Valencia I63 I, ff. 23-27v, cf. also Molina (note 5I), p. 4I.

79 Gazulla (note 56), p. 6i4.

80 This is the case of the relief with the same subject in Ancona, Museo Diocesano, catalogued as Italian, twelfth-thirteenth centuries. Cf. Davis (note 75), p. 33 . 


\section{Byzantium and beyond: sacred images in a brave new kingdom}

These shrines contained from the beginning cult images endowed with charisma. The icons were offered up for public veneration and allegedly performed miracles or interacted in some way with a non-human dimension. ${ }^{81}$ For instance, Our Lady of Purity was an icon related to the miraculous rescue of a young woman at risk of shipwreck in the fifteenth century. The girl had promised to enter as a nun in the convent if she and her father were able to arrive safely when travelling from Mallorca to Valencia. ${ }^{82}$ Only modern engravings of this icon have survived to the present day, but its figurative appearance resembles that of ancient cult images, and objects of veneration in Valencian sanctuaries, and shares the ability to independently perform miracles.

Certainly, legends about the origins of Valencian icons seldom tell us the historical truth, since they usually claim a Mediterranean provenance, from Tuscany, Venice or from a Byzantine tradition already melded into an artistic lingua franca by the thirteenth century. The exotic appearance of images was probably perceived as a symptom of sacred alterity prompting public worship. The aura of each image was not conferred by the artist, whose name is often forgotten if ever known, but rather by its extraordinary origins or by the circumstances in which it could function, and by where it had been found, transferred or originated, especially when connected to the birth of the Christian kingdom and to the person of James I. Soon, miracles and a supernatural agency were assigned to them. For example, the icon of El Puig combined invocation of the apostolic origins of the worship of the image and of its acheiropoietic nature. An institution introduced or appropriated them in order to gain or confirm prestige or claim privileges. Replicas and other derivative images were often commissioned, which in turn drew attention to the fame of the original. The respective owners or institutions entrusted to guard these icons, such as the cathedral or the monasteries, managed to harness them to their own needs in terms of

8 I Bacci, Michele, Il pennello dell'Evangelista, Pisa I998, p. 20.

82 Blaya Estrada, Oriente en Occidente (note I3), p. 3 I; quoting previous narrative sources, mainly Sorribas, José, Narración histórica de la antigüedad y progresos del Real Monasterio de la Purísima Concepción de la ciudad de Valencia, Valencia I74I; Teixidor (note 26), II, p. I29; Andrés Antón, María Pilar, El Monasterio de la Puridad. Primera fundación de clarisas en Valencia y su reino. Siglos XVI-XVIII, Valencia I993. 
self-representation. ${ }^{8}$ This general assertion was particularly true in Valencian cases, since the paucity of sacred relics increased the value of images lending authority to the monarchy and protection to the Christian faithful.

Acheiropoietic images continued to be invoked in order to demonstrate the authenticity of an icon, to establish its remote origins in apostolic times, and to explain its strange and mysterious appearance; and, last but not least, to justify new forms of worship developed later in the Kingdom of Valencia. The icon not made by human hands would serve as a model for successive images to which were thus imbued with some of its otherworldliness; but it also subjected them to a formal dependence in terms of certain Byzantine features. This process led to a conscious imitation of archaic, but also perfectly valid, prototypes more and more distanced from new trends inspired by Italian Trecento and later Flemish panel painting. ${ }^{84}$ The presence of Byzantine icons should not be neglected as a factor contributing to the prestige of oriental models for sacred painting. Images from Romania - which means not only Constantinople and Pera but in the wider sense other lands under Byzantine control before I 204 - were relatively common in Valencian inventories, as recent research has proved. ${ }^{85}$ Surviving icons such as Our Lady of Grace, Our Lady of Montolivet, Our Lady of the See and other similar works do indeed reflect the wide spread of these models in Valencian chapels, monasteries and houses, even if their precise origins remain largely unknown. One remarkable exception is the oratory "from Candia", mentioned in I 439 in the inventory of the Valencian residence of the Venetian merchant Pietro de Victori, who also owned a chest decorated with "Greek-style works". ${ }^{86}$ A general adscription to workshops meeting

83 Belting (note 77) p. 348 .

84 Ainsworth, Maryan W., À la façon grecque: The Encounter of Northern Renaissance Artists with Byzantine Icons, in: Byzantium. Faith and Power (I 26I-I 557), Ed. Evans, Helen C., New Haven/London 2004, pp. 545-555; Benito Domenech, Fernando and Gómez Frechina, José, La Clave Flamenca en los Primitivos Valencianos, Valencia 200I, pp. 76-90; Pereda, Felipe, Las imágenes de la discordia. Política y poética de la imagen sagrada en la España del 400, Madrid 2007, pp. 2 I 7-232.

85 Miquel Juan, Matilde, Retablos, prestigio y dinero. Talleres y mercado de pintura en la Valencia del gótico internacional, Valencia 2008, pp. I I 5-I I6; García Marsilla, Juan Vicente, Art i societat a la València medieval, Catarroja 20 I I, p. I 88; Duran i Duelt, Daniel, Icons and minor arts: a neglected aspect of trade between Romania and the Crown of Aragon, in: Byzantinische Zeitschrift ios (2012), pp. 29-52.

86 García Marsilla (note 85), p. I88. 
the demands of Latin and Western customers is acceptable, but deserves further research, given the complexity of this kind of production. ${ }^{87} \mathrm{No}$ less interesting is the effect that this particular interpretation of maniera greca, known as obra de Romania, exerted on Valencian painting, either in the conception of the sacred image or in the language adopted by artists working for the local market.

A panel depicting the life of Saint Luke, in Valencia Fine Arts Museum, illustrates very vividly this idea in the late fourteenth century: the Virgin appears to the Evangelist and offers him a board with a portrait of her painted in frontal view; it depicts very closely the details of Mary's face (Ill. I I 2). ${ }^{88}$ This narrative scene confirms, on a visual level, the strong belief in supernatural images, their sacred otherness, fostering their public worship no less than their devotional function when in the possession of an individual. This was certainly true in the case of the Veronica of the Virgin, associated with King Martin I as an object of personal devotion, but also the object of a public cult when it was chosen as representation of the Immaculate Conception of Mary. ${ }^{89}$ It is worth noting that the legitimization of this portrait of the Virgin was based, as fray Francesc Eiximenis declared, on the Marian icon venerated in the Franciscan church of Santa Maria in Aracoeli in Rome. ${ }^{90}$

A close connection to monarchy is often present at the inception of shrines and the donation of the images. On the one hand, an itinerant kingship needed to maintain its presence on the urban stage, and one the best ways to do this was to associate the royal image and patronage to the most venerated icons, placed in popular shrines accessible either to the population of Valencia, or to pilgrims, merchants and all kinds of travellers-something of the Virgin's Byzantine role as army leader and bringer of victories survived in several of these icons, especially in El Puig. On the other hand, royal donation conferred prestige and antiquity to cult images, giving account of their remote origins at the moment of birth of the new Christian kingdom.

87 Bacci (note 43), pp. 494-510.

88 Valencia, Museo de Bellas Artes, anonymous, attributed to Llorenç Saragossà, last quarter of the fourteenth century.

89 Crispí Antón, Marta, La difusió de les Veròniques de la Mare de Déu a les catedrals de la Corona d'Aragó a finals de l'Edat Mitjana, in: Lambard XI (1996), pp. 83-103; Crispí Antón, Marta, La Verònica de Santa Maria i la processó de la Puríssima organitzada per Martí l’Humà, in: Locus amoenus 2 (1996), pp. 85-I0I.

90 On this Madonna di Santa Maria in Aracoeli and its cult, cf. Bacci (note 8I), pp. 263-265 and p. 327 for its Spanish counterparts. 
However, the role of religious orders can hardly be underestimated. Mendicants and Dominicans in particular (Saint Vincent Ferrer in the Christ of el Grao; Francesc Eiximenis in the cult of Veronica), but also the friars of Our Lady of Mercy (Saint Peter Nolasco); nuns and prelates setting out from these religious institutions performed significant work leading to a growth and spread of the cult of these sanctuaries, and provided them with a doctrinal and legendary background. We must remember that the ways and times at which these icons could be exposed and venerated are also significant. They served to orientate the perception and ritual attitude of the faithful. ${ }^{91}$

Although these places of worship did not usually achieve international status as centres of pilgrimage, it is also true that they were known to travellers as the Sante Parole claims, and were connected to a network of international - mainly Mediterranean - sanctuaries because of their alleged origins and/or their figurative likeness to famous and prestigious prototypes. One way or another they lent consistency to a Christian community in a brave new Kingdom. Part of this function was fulfilled by contrast with other religious identities, as might be expected, and it involved a certain polemical aspect vis à vis Muslims (Our Lady of El Puig) or Jews (Passio Imaginis and Christ of El Salvador and Christ of El Grao).

All in all, one can perceive how several layers of meaning were stratified within these icons and their sanctuaries. Some of them can be easily distinguished, such as the historical reference to the foundation of the Kingdom or the legendary claims to apostolic origins of their worship. Others, in contrast, reflect changing meanings and adaptations to new circumstances in religious coexistence or confrontation; sometimes they even raise further questions about the preferences of donors, patrons or institutions, as may be the case for the famous triptych painted by Bartolomé Bermejo and the Osonas for the Italian merchant Francesco dalla Chiesa as a consequence of a vow made to the Virgin of Montserrat after being miraculously healed. This work was destined to cross the sea to the dalla Chiesa chapel in Acqui cathedral, helping to spread the cult of a Marian sanctuary abroad. In fact, the economic and demographic growth of Valencia and the city's political leadership under the Crown of Aragon turned the capital of the kingdom into an international centre ready to draw in merchants, humanists, princes of the Church, artists and all kinds of travellers, and the bequest of most of the relics of the royal chapel in 1437 reinforced Valencia's position in the holy portolan charts.

9I Bacci (note 8I), p. 28. 
Illustrations 


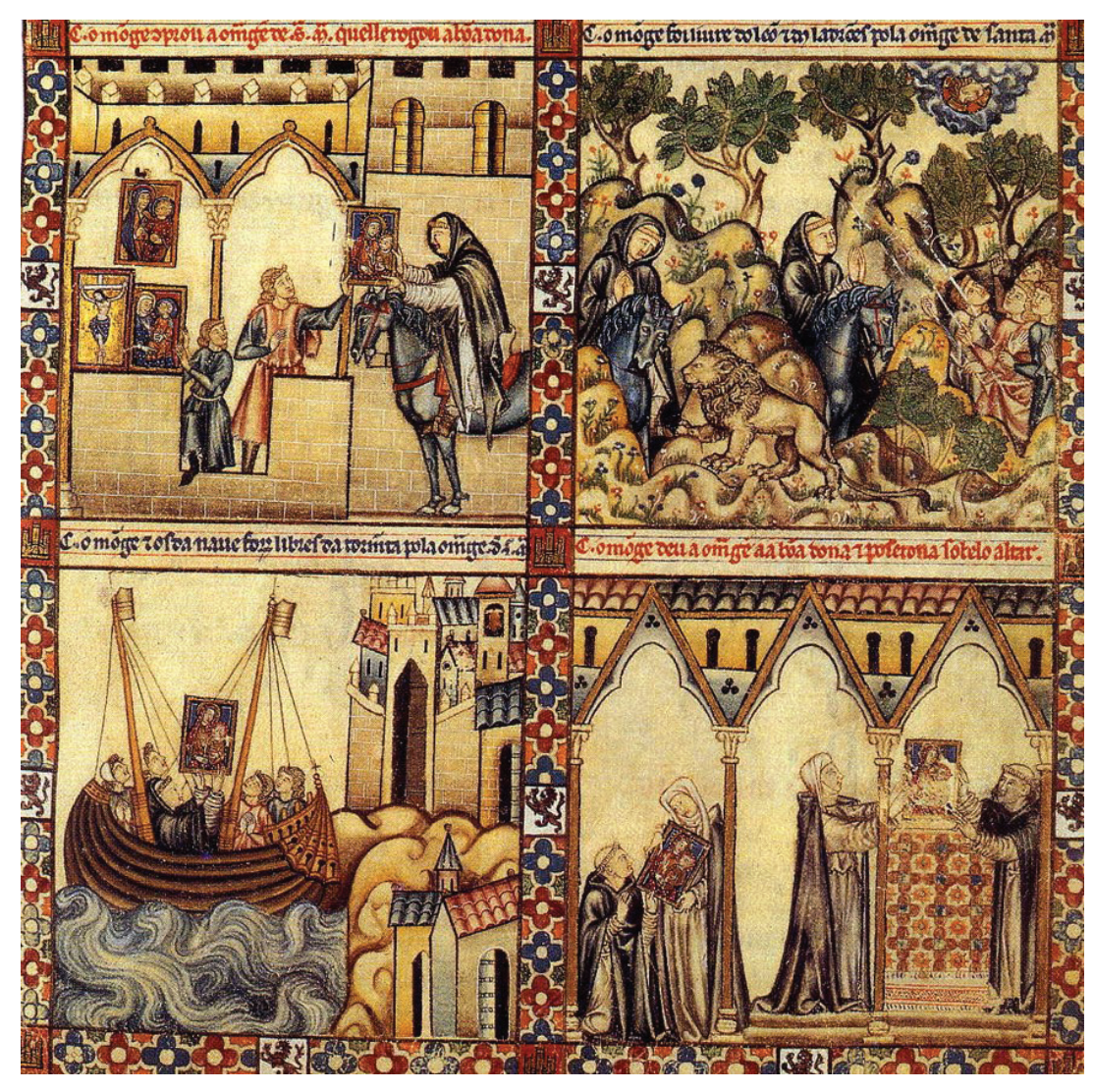

Ill. I03 - Illuminator of Alfonso's X workshop, Miniature of Cantigas de Santa María, Rich Codex, ca. I 272-I 284, San Lorenzo de El Escorial, Biblioteca del Real Monasterio, T-I-I, cantiga 9, f. I7r (Patrimonio Nacional). 


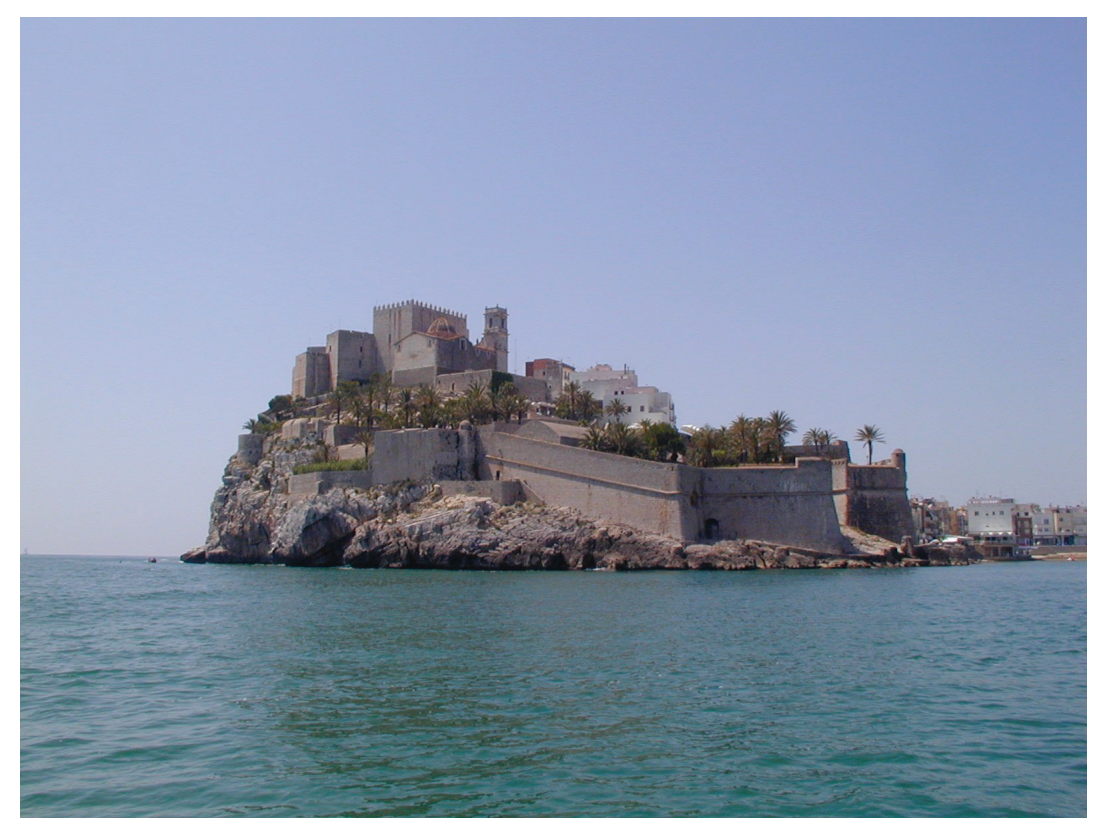

Ill. I04 - Peñiscola (Castellón), the castle and the medieval city. 


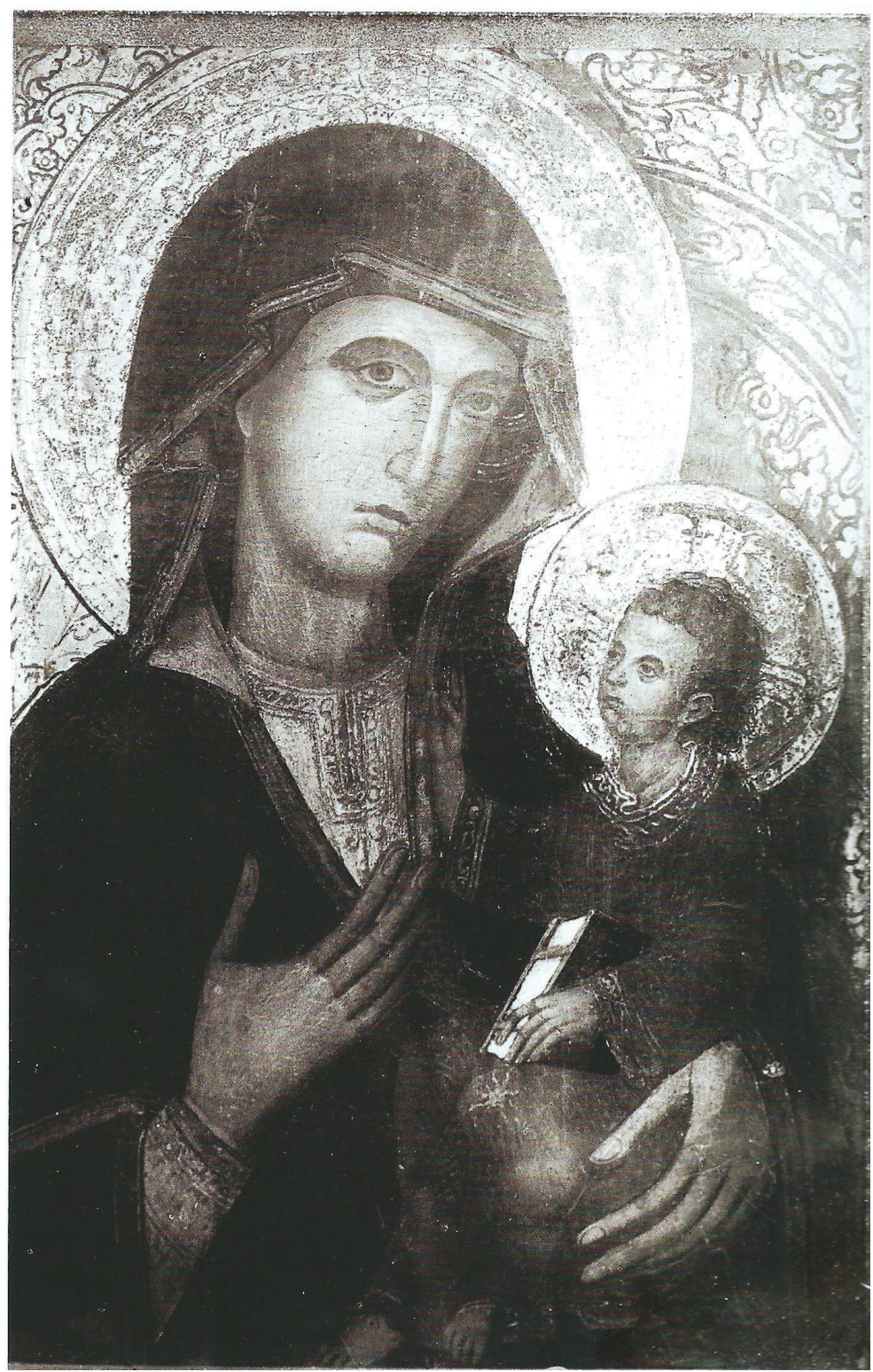

Ill. Ios - Mediterranean painter, Our Lady of the See (Nuestra Señora de la Seo), Icon, $3_{3}^{\text {th }}$ century, Valencia, Cathedral (before 1936). 


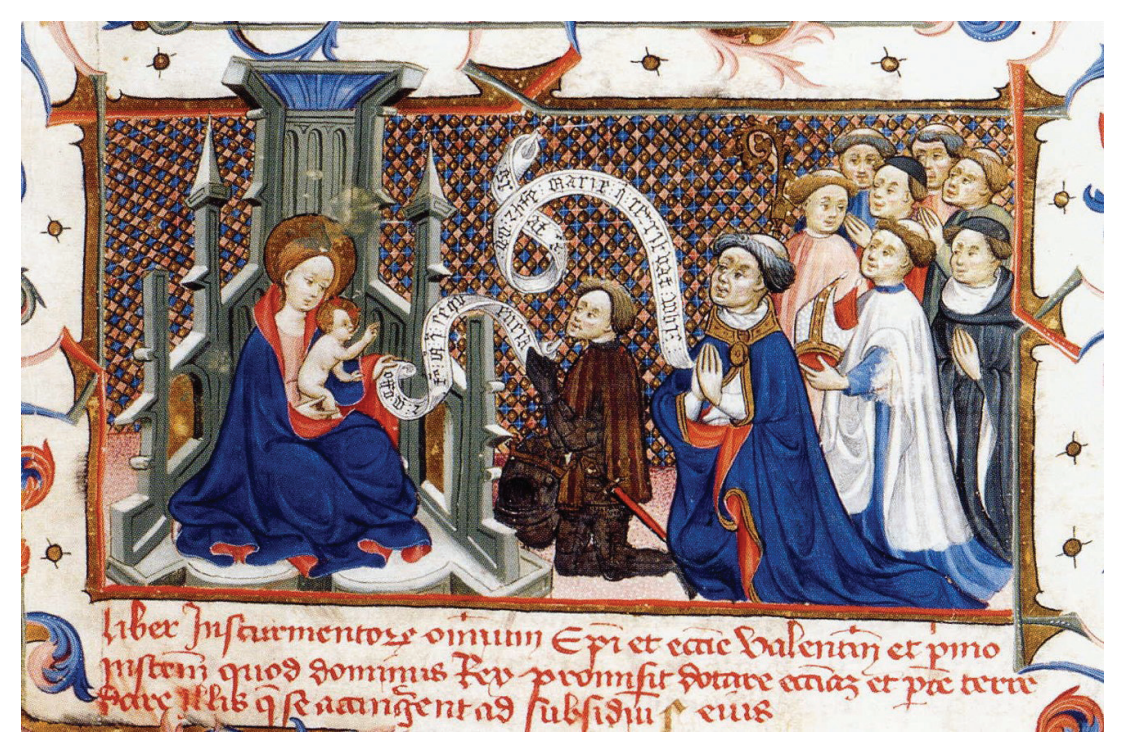

Ill. 106 - Liber Instrumentorum Master (Domingo Adzuara?), Miniature of King James I and the Bishop of Valencia offering the foundation of the new Cathedral to Saint Mary, Valencia, Cathedral, Biblioteca Capitular, ms. I62, f. 6 r. 


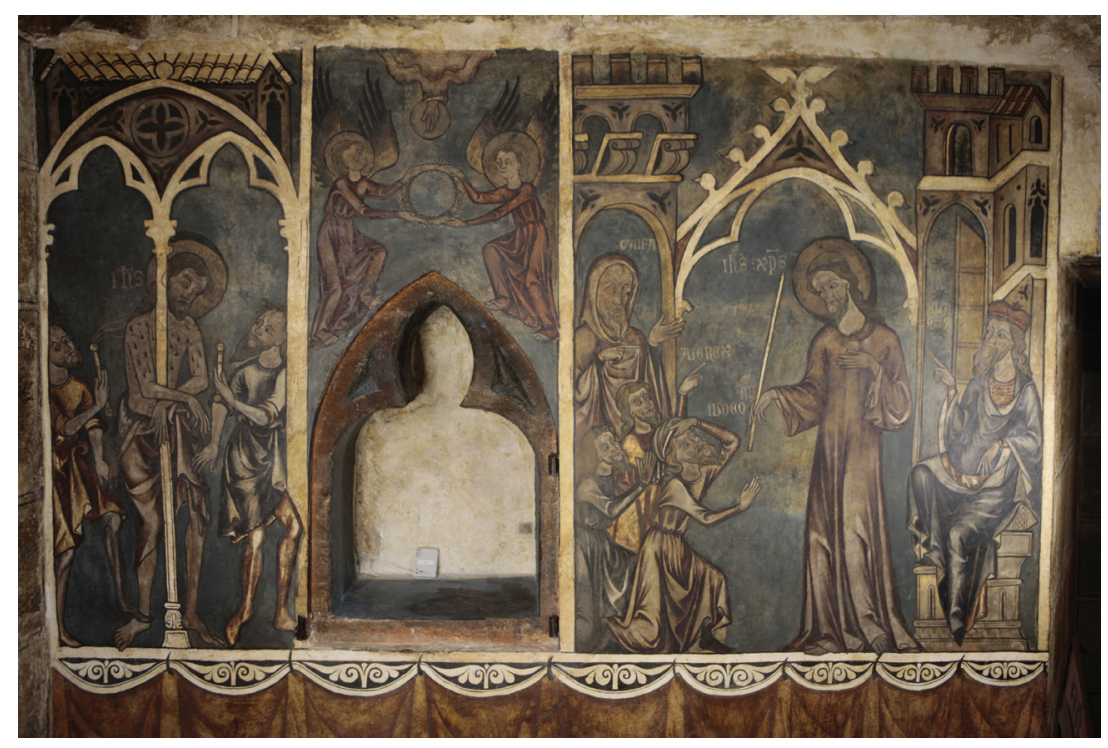

Ill. I07 - Painter from the Crown of Aragon, Wall paintings with scenes of Christ's Passion, ca. I 256-I 280, Cathedral, secret chamber (reconditorio), (Image courtesy of Subdirección de Conservación, Restauración e Investigación IVC+R [Culturarts], Generalitat Valenciana. 


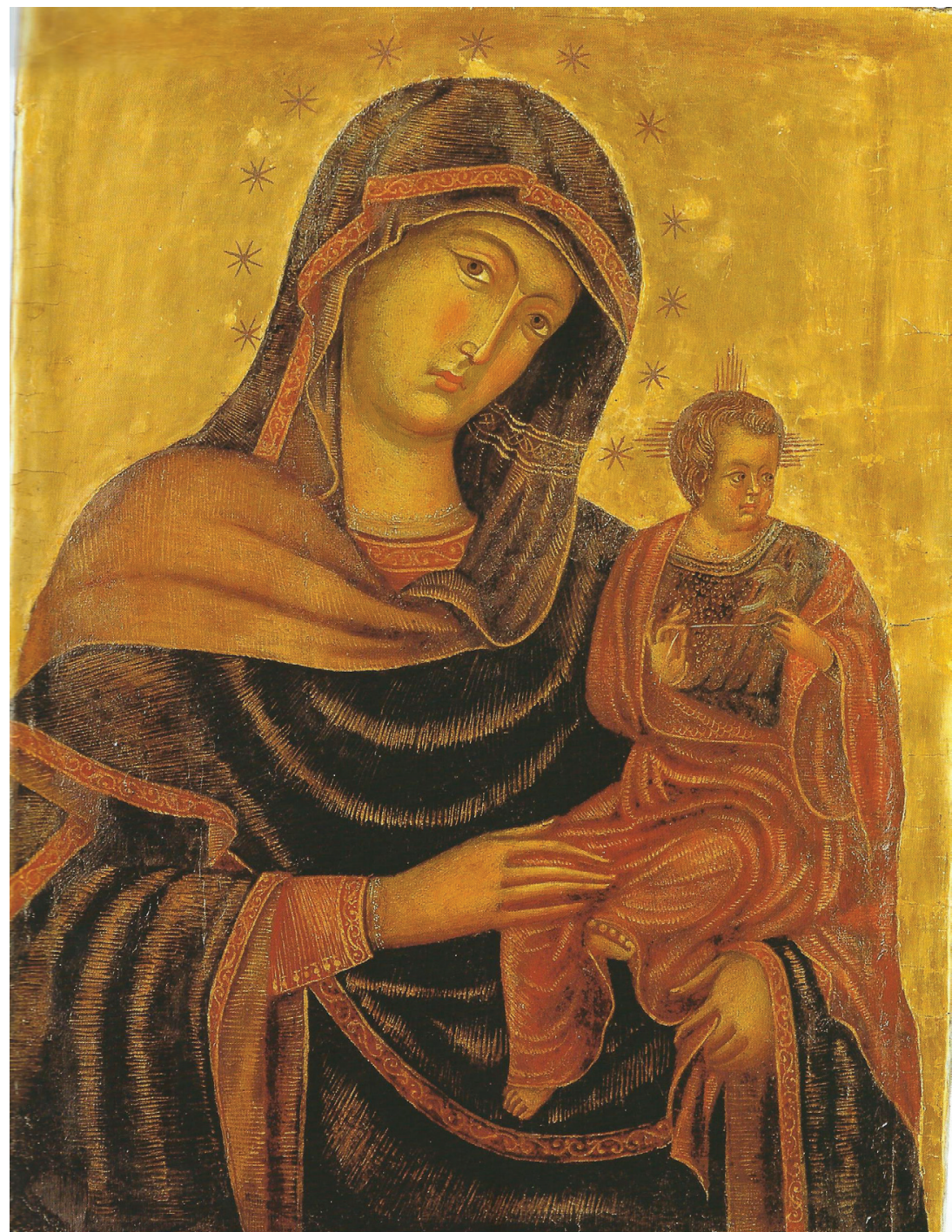

Ill. I08 - Italian painter, Our Lady of Grace (Nuestra Señora de Gracia), ca. I270-I 300, Valencia, Saint Augustine’s parish church. 


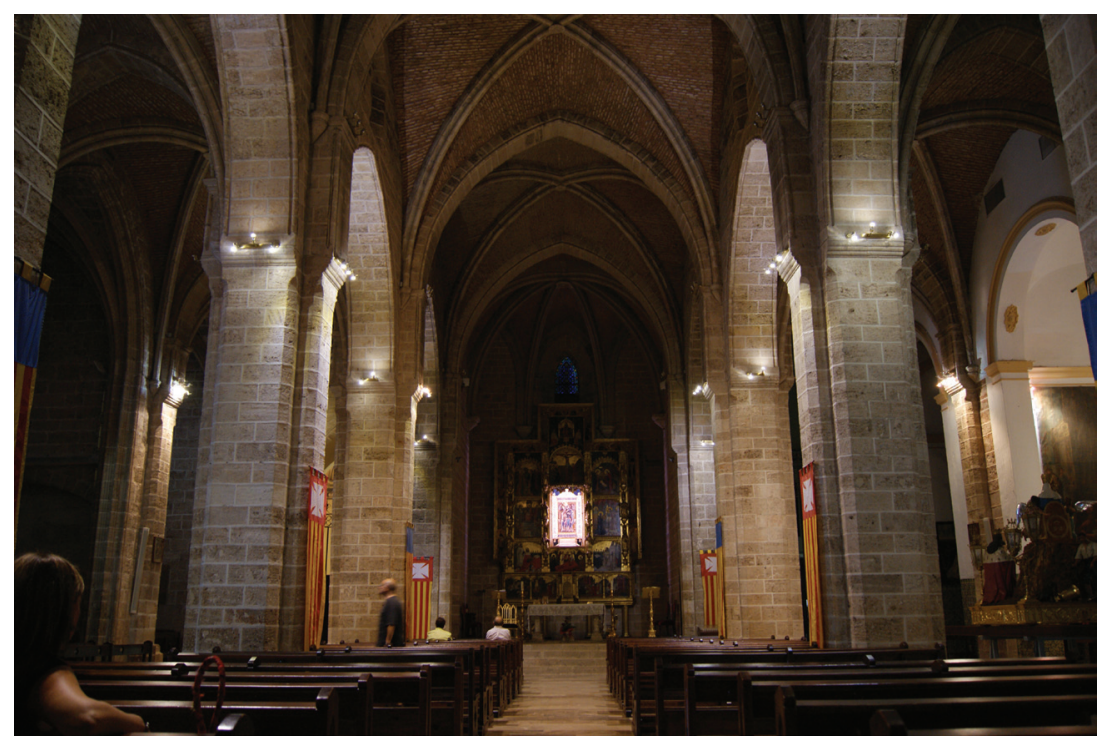

Ill. ro9 - Valencia, El Puig de Santa María, Monastery of Santa María del Puig, I 3 th-I 8 th centuries. 


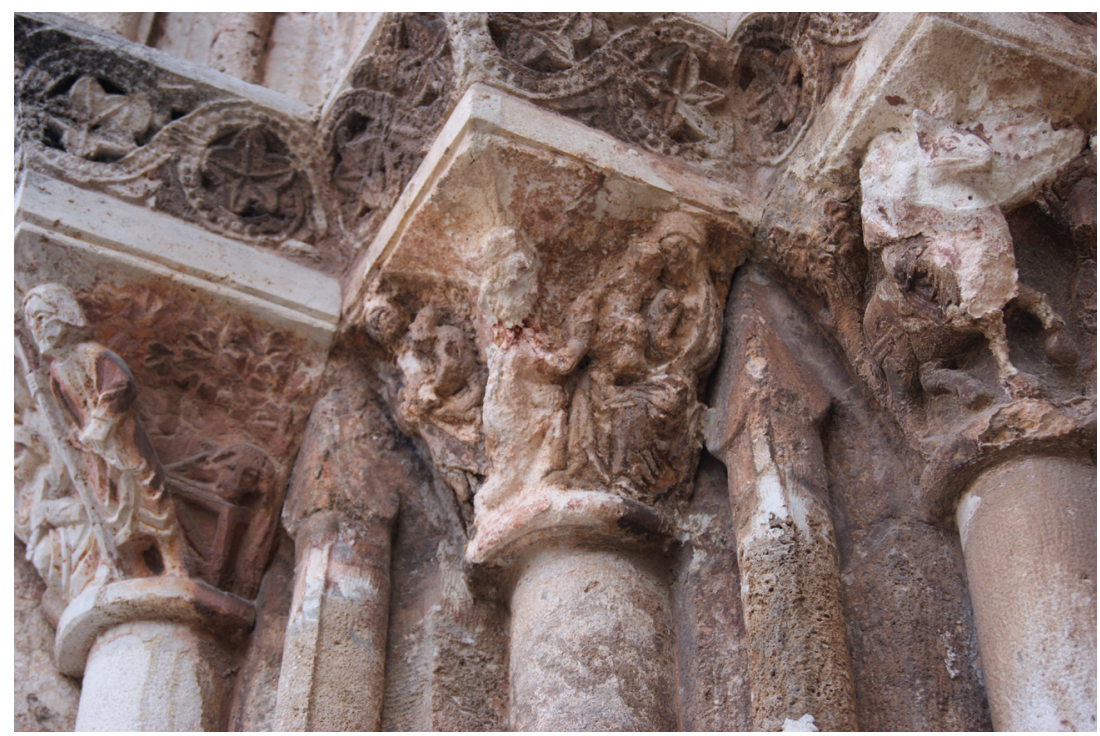

Ill. I Io - Valencia, El Puig de Santa María, Capital on the portal of the church of Saint Mary, I 3 th century, Sculpture workshop from the Crown of Aragon. 


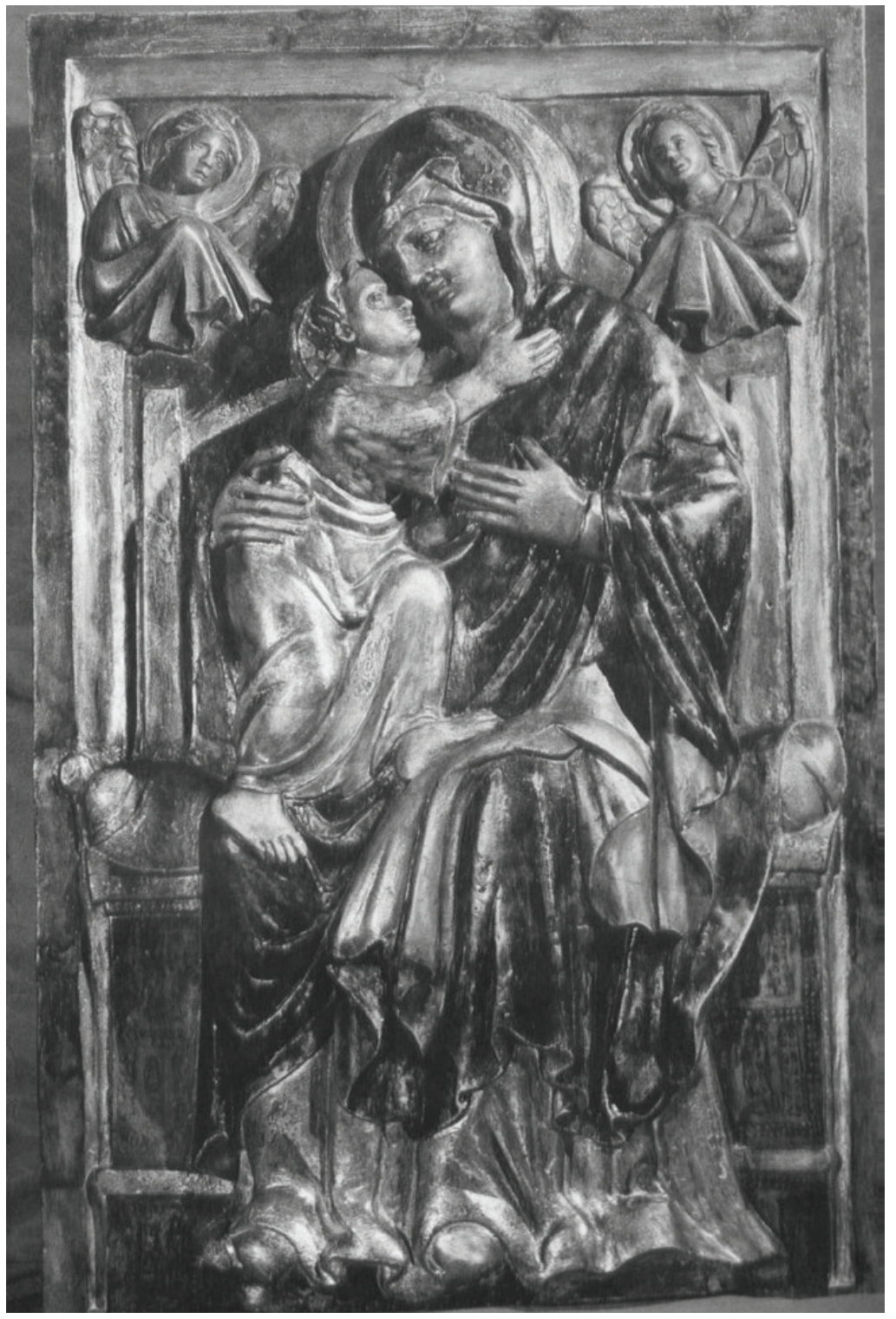

Ill. I I - Valencia, El Puig de Santa María, Monastery of Santa María del Puig, Madonna with Child, Relief Icon, second half of the I 3 th century Italian sculptor. 


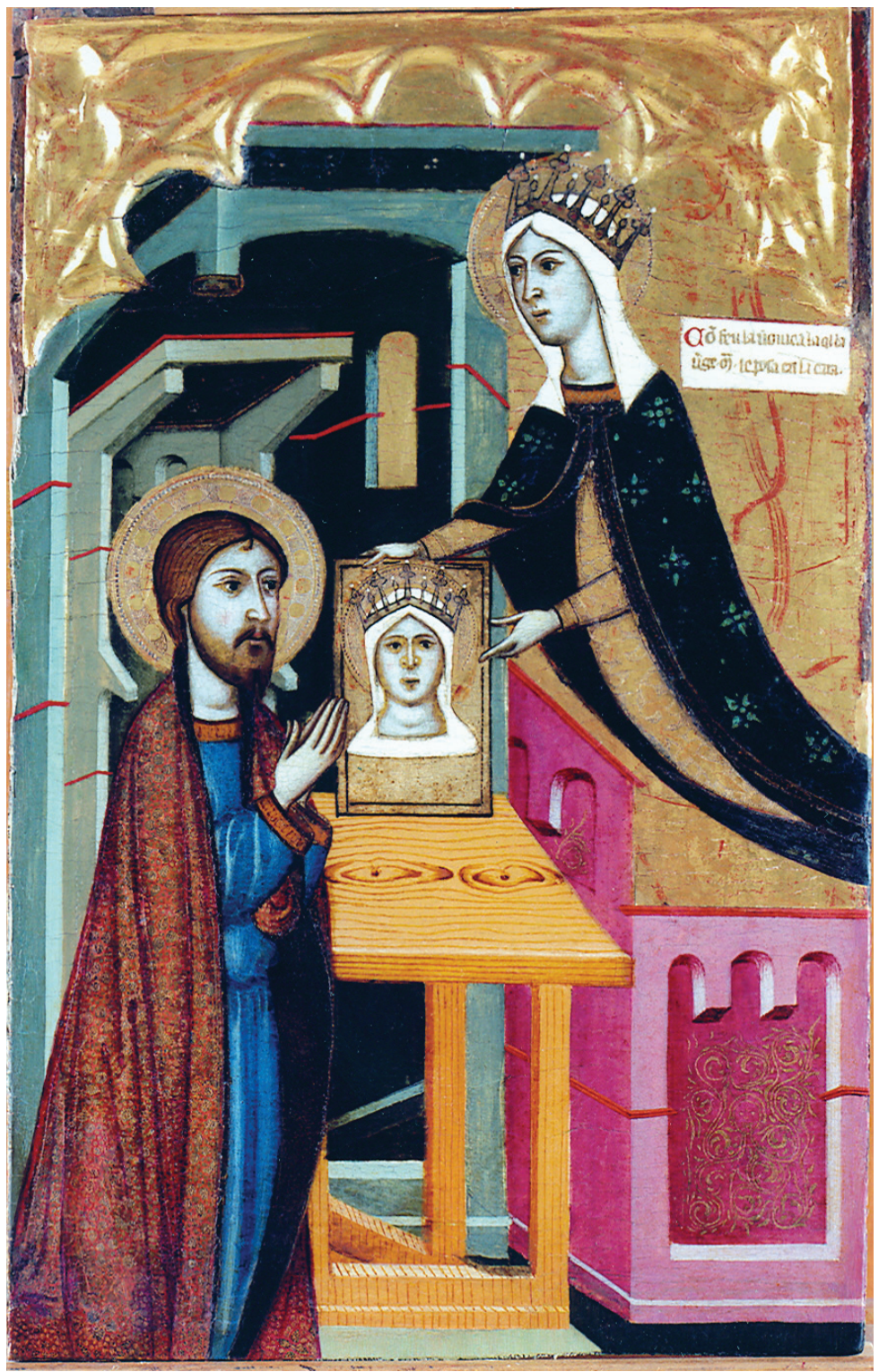

Ill. I I 2 - Llorenç Saragossà (attributed to), Saint Luke receives an icon with the portrait of Saint Mary, ca. I 370-1380, Valencia, Museo de Bellas Artes. 